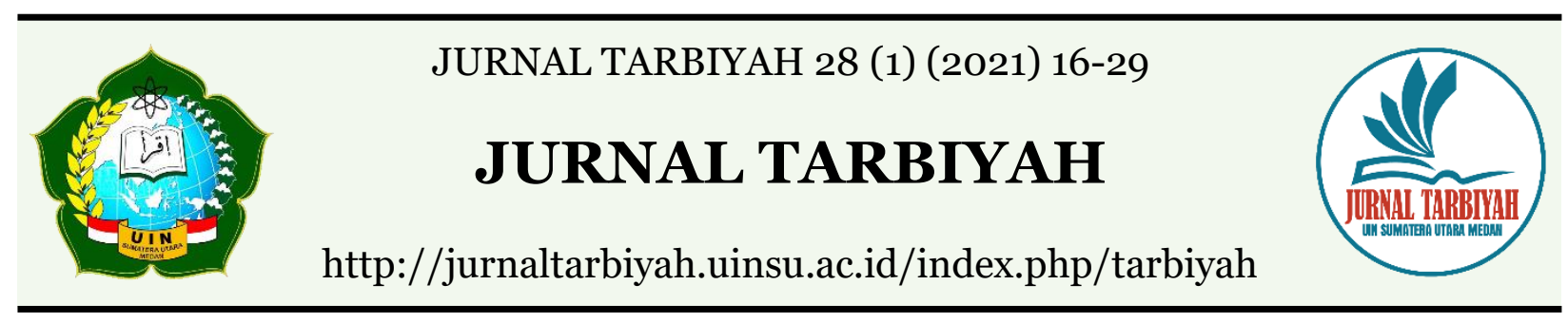

\title{
THE ANALYSIS OF EFFECT SIZE AND THE EFFECT OF TEACHING MATERIALS BASED ON PROBLEM BASED LEARNING (PBL) ON STUDENTS' COMPETENCE
}

\author{
Syamina $^{1}$, Asrizal $^{2}$, Festiyed $^{3}$ \\ ${ }^{1}$ Pascasarjana Pendidikan Fisika FMIPA Universitas Negeri Padang, Padang, Indonesia \\ 2,3 Staf Pengajar Jurusan Fisika FMIPA Universitas Negeri Padang, Padang, Indonesia \\ Email: ${ }^{1}$ syamina5398@gmail.com, ${ }^{2}$ asrizal@fmipa.unp.ac.id, \\ 3 festiyed@fmipa.unp.ac.id
}

DOI : 10.30829/tar.v28i1.897

Accepted: January 20th, 2021. Approved: June 28th, 2021. Published: June 3oth, 2021

\begin{abstract}
Science in the 21st century continues to develop. With these developments, Indonesia must prepare young people who are ready for change and able to face the challenges that exist in the 21st century. The 21st century has more complex challenges. Various efforts have been made by the government to meet the demands of the 21st century, including reforming educational standards. The 2013 curriculum requires students to be active in the learning process. Learning methods and models that are expected to be able to develop students' abilities, and in accordance with the implementation of the 2013 curriculum, are problem-based learning. Therefore, researchers are interested in finding the effect of PBL-based teaching on student learning outcomes through meta-analysis with effect size. Based on the analysis conducted on 20 journals related to PBL-based teaching materials, there are three conclusions in this study. First, PBL-based teaching materials are effectively used at the junior and senior high school levels with a high effect size category. Second, PBL-based teaching materials have the highest category of effectiveness in improving science process skills. Third, based on the teaching materials used, teaching materials in the form of electronic media (IT) based on PBL are effective in improving student learning outcomes.
\end{abstract}

Keywords: 21st century, teaching materials, Problem Based Learning, effect size 


\section{INTRODUCTION}

Science continues to develop in the $21^{\text {st }}$ century. The development of science can be seen from different aspects, such as technological development, new discoveries of scientific and social research, industrial revolution and so on. With these developments, Indonesia must prepare young generations who are ready and able to face challenges of the $21^{\text {st }}$ century.

The $21^{\text {st }}$ century has more complex challenges than previous century. These challenges include critical thinking, collaboration and leadership, adaptability, initiative and entrepreneurial skill, oral and written communication skill, ability to access and analyze information, as well as curiosity and imagination (Wagner, 2010). These challenges must be faced by generation these days along with the increasing of students' competence. Therefore, it is necessary to have a supportive education system.

The government has made various efforts to meet the demands of the $21^{\text {st }}$ century, including to reform the educational standards; the standards for educators and education staff, the standards of facilities and infrastructure, the competency standards for graduates, content standards, process standards, management standards, education financing standards and educational assessment standards. One of the government's efforts to improve the standard of facilities and infrastructure is developing the curriculum. The curriculum continues to be developed, and the latest one is known as the 2013 curriculum.

The 2013 curriculum is a curriculum that involves students actively in learning, or what is known as student-centered approach. The activities include observing, asking, trying, reasoning and communicating (Syam, 2017). The teacher acts as a facilitator in the 2013 curriculum. This curriculum consists of several competencies that must be achieved including attitudes, knowledge and skills. To implement the 2013 curriculum well, appropriate strategies and learning methods are needed in learning.

One of the suitable learning models for the 2013 curriculum is the Problem Based Learning (PBL) model. This is in line with Riyanto (2016) who explained that several lessons for the 2013 curriculum include discovery learning, inquiry learning, problembased learning and project-based learning. The PBL model stimulates students to think carefully and deeply before finding a conclusion from a particular lesson. Therefore, it is suitable to impelement the 2013 curriculum in order to encourage students' activeness in learning. 
However, the situation in the field is actually different from the ideal situation above. Based on information retrieved from related journals, several gaps were found between the ideal situation and the situation in the field. First, the teaching materials used by the teacher are still in the form of conventional teaching materials, not teaching materials prepared by the teachers themselves (Jauhariyah). The second problem is that according to Nurhayati et al (2019), the implementation of learning is still teachercentered, so students' activeness in developing communication and collaboration skills is reduced.

Based on the problems above, the solution offered is the development of PBLbased teaching materials. Researchers are interested in analyzing the effect of several teaching materials developed using the PBL model. The effect will be analyzed using the Effect Size (ES) equation. The purpose of this study is to see the effect of PBL-based teaching materials on students' competence in terms of several aspects, such as; educational level, types of teaching materials, and the competence of students themselves.

\section{LITERATURE REVIEW}

\section{Teaching Materials}

One of the means of supporting learning is teaching materials. According to the Ministry of Education (2008), teaching materials are all forms of materials used to assist teachers/ instructors in carrying out the learning progress in the classroom. There are several types of teaching materials, namely printed teaching materials, such as handouts, books, modules, worksheet and brochures, audio-visual teaching aid such as radio, cassette, or visual aid, such as photos, pictures, and models, and multimedia teaching materials such as interactive CDs, computer based, internet. Teaching materials can be adapted to the characteristics of the learning material to enable students in learning a competency coherently and systematically.

The preparation of teaching materials is carried out systematically by referring to the standard rules in the preparation of teaching materials according to the Ministry of National Education (2008) as follows.

a. Learning instructions, explaining how the use of teaching materials by teachers and students.

b. The competencies that will be achieved by students consist of core competencies, basic competencies, indicators and objectives for achieving learning outcomes. 
c. Learning materials are described in accordance with the needs analysis of Core Competence / Basic Competence so as to be able to achieve the expected learning objectives.

d. Supporting information consists of various additional information related to the subject matter that can complement the teaching materials and make it easier for students to master the knowledge they have acquired. In the supporting information, character values are also presented along with descriptions and indicators of character values that can be used by students as a guide in exploring character values from within themselves.

e. The exercises contain tasks given to students to train, and familiarize students with developing their abilities, both attitudes, knowledge and skills.

f. Worksheets contain work instructions that guide students during practical activities.

g. The evaluation contains a number of questions addressed to students to measure the extent to which competency mastery can be achieved after participating in learning activities. While the response / return contains the answers to the questions contained on the evaluation sheet.

h. Response or feedback on evaluation results.

\section{Problem Based Learning (PBL)}

Problem Based Learning (PBL) is one model that is suitable to be applied to the 2013 curriculum. In practice, this model stimulates students to overcome the problems given so that students have high motivation in learning and can improve their critical thinking skills and problem solving skills (Novita et al. , 2019). The PBL model is suitable to be integrated in the form of teaching materials that contain real problems related to Physics so that learning can be more meaningful. This is in line with Asrizal et al (2018) which stated that learning will be meaningful if students experience an event directly so that the information obtained is stored for a long time in their memory.

\section{The Learning of Natural Science}

Essentially, learning is an activity involving interaction between teachers and students simultaneously. Sanjaya (2006) explains that learning is a series of activities that involve various components of learning which include objectives, materials, methods, strategies, media and evaluations that interact with each other in a learning process. The 
final result expected from the learning process is a change in a person's behavior after going through the learning process. In other words, learning is a process that involves several components, namely students, educators and learning resources that aim to help students learn well.

Natural Science is a part of science that originally came from the word "Scientia" which means "I know". Science in its development is often understood as natural science only. Trianto (2007) states that science is knowledge obtained through data collection and experimentation, observation, and deduction to produce an explanation of a symptom. Natural Science studies the universe, objects that exist on the surface of the earth, in the deep part of the earth and in outer space, both those that can be observed by the senses and those that cannot be observed by the senses. Therefore, the understanding of science must be understood first in explaining the nature of physics. Based on the explanation above, it can be concluded that science is a systematic collection of theories where its application is generally limited to natural phenomena, born and developed through scientific methods such as observation and experimentation and demands scientific attitudes such as curiosity, openness, honesty and so on.

\section{The Learning of Physics}

One of the subjects in schools, especially in High School/ Islamic High School is Physics. Physics is one of the scientific fields that discusses natural phenomena and phenomena and the interactions in them. Referring to Permendikbud Number 59 of 2014, physics is part of the Natural Sciences which is a systematic effort in order to build and organize knowledge in the form of explanations that can be tested and are able to predict natural phenomena.

According to the Regulation of the Minister of Education and Culture Number 59 of 2014, the physics subject given to High School and Islamic High School students aims to:

a. Increase students' faith by realizing the relationship of order, beauty, and complexity of nature in the universe to the greatness of God who created it.

b. Demonstrate scientific behavior in (curiosity, objective, honest, thorough, careful, tenacious, diligent, careful, responsible, open, critical, creative, innovative, and cares about the environment) in daily activities as a manifestation of the implementation of scientific attitude in conducting experiments and discussions. 
c. Appreciate the work of individuals and groups in daily activities as a form of implementation of carrying out and reporting experimental results, fostering a scientific attitude that is honest, objective, open, tenacious, critical, and able to work together.

d. Develop experience in using the scientific method in formulating problems, proposing and testing hypotheses through experiments, designing and assembling experimental instruments, collecting, processing, and interpreting data, as well as communicating experimental results orally and in writing.

e. Develop reasoning skills in inductive and deductive analytical thinking by using concepts and principles of physics to explain various natural events and solve problems both qualitatively and quantitatively.

f. Mastering the concepts and principles of physics and having the skills to develop knowledge and self-confidence as a provision to continue education at a higher level and develop science and technology.

\section{Students Competence}

Competence is the final ability that is expected as a result of learning. Learning outcomes are abilities possessed by students after going through the learning process (Sudjana, 2002). Assessment of learning outcomes by teachers is carried out systematically, continuously and it covers all aspects of the students themselves, including skills, attitudes, or other new habits acquired during the learning process. According to BSNP (2007), the purpose of assessing learning outcomes by teachers is to monitor the learning process and progress of students and to increase the effectiveness of learning activities. Therefore, the assessment of learning outcomes is one of the important things to do in learning.

\section{RESEARCH METHOD}

In analyzing the data obtained from various journals, the author uses an analysis called meta-analysis which is conducted by means of effect size analysis. Meta-analysis is a quantitative analysis using a large amount of data and applying descriptive methods by practicing it in organizing a number of information from a large sample whose function is to complete certain goals (Glass, McGaw, \& Smith, 1981). Several stages were carried out in this research, starting from searching the literature to formulate research 
problems, collecting journals to be analyzed, then analyzing the effect size values of journals using the following equations.

1. The Mean of a group

$$
E S=\frac{\bar{x}_{\text {post }}-\bar{x}_{\text {pre }}}{S D_{\text {pre }}}
$$

Description:

$$
\begin{array}{ll}
\overline{E S} & : \text { Effect Size } \\
\bar{x}_{\text {pre }} & : \text { The mean score of pre-test } \\
\bar{x}_{\text {post }} & : \text { The mean score of post-test } \\
S D_{\text {pre }} & : \text { Standard Deviation of Pre-test }
\end{array}
$$

2. The Mean and Standard Deviation of every group (two groups, post test only)

$$
E S=\frac{\bar{x}_{E}-\bar{x}_{C}}{S D_{C}}
$$

Description:

$$
\begin{array}{ll}
\overline{E S} & : \text { Effect Size } \\
\bar{x}_{C} & : \text { The mean score of post-test from the control group } \\
\bar{x}_{E} & : \text { The mean score of post-test from the experimental group } \\
S D_{C} & : \text { Standard Deviation of pretest }
\end{array}
$$

3. The Mean and Standard Deviation of every group (two groups, pre-post test)

$$
E S=\frac{\left(\bar{x}_{\text {pos }}-\bar{x}_{\text {pre }}\right)_{E}-\left(\bar{x}_{\text {pos }}-\bar{x}_{\text {pres }}\right)_{C}}{\frac{S D_{\text {prec }}+S D_{\text {pre }}+S D_{\text {posc }}}{3}}
$$

Description:

ES : The mean score of Effect Size

$\bar{x}_{\text {pre }} \quad$ : The mean score of pre-test

$\bar{x}_{\text {post }} \quad$ : The mean score of post-test

$\left.\overline{(x}_{\text {pre }}\right) c \quad$ : The mean score of pretest from the control group

$\left.\overline{(x}_{\text {post }}\right) c \quad$ : The mean score of pos-test from the control group

$\left.\overline{(x}_{\text {pre }}\right) e \quad$ :The mean score of pre-test from the experimental group

$\left.\overline{(x}_{\text {post }}\right) c:$ The mean score of post-test from the experimental group

$S D_{\text {prec }} \quad$ : The score of Standard Deviation of pre-test from the control group

$S D_{\text {post }} c$ : The score of Standard Deviation of post-test from the control group

$S D_{\text {pree }} \quad$ : The score of Standard Deviation of pre-test from the experimental group

$S D_{\text {post }} e:$ The score of Standard Deviation of post-test from the experimental group 
4. If the Standard Deviation is unknown then it can be obtained through T-test

$$
E S=t \sqrt{\frac{1}{n_{E}}+\frac{1}{n_{C}}}
$$

Description :

$$
\begin{array}{ll}
\mathrm{ES} & : \text { Effect Size } \\
\mathrm{t} & : \text { The result of T-test } \\
\mathrm{nE} & : \text { the total sample of experimental group } \\
\mathrm{n}_{\mathrm{C}} & : \text { the total sample of control group }
\end{array}
$$

The criteria of effect size can be seen in the following table.

Tabel 1. The Criteria of Effect Size (ES)

\begin{tabular}{ccc}
\hline No & ES & Kategori \\
\hline 1 & ES $\leq$ 0,15 & $\begin{array}{c}\text { Dapat } \\
\text { diabaikan }\end{array}$ \\
\hline 2 & $\begin{array}{c}0,15<\mathrm{ES} \\
<0,40\end{array}$ & Rendah \\
\hline 3 & $\begin{array}{c}0,40<\mathrm{ES} \\
<0,75\end{array}$ & Sedang \\
\hline 4 & $\begin{array}{c}0,75<\mathrm{ES} \\
<1,10\end{array}$ & Tinggi \\
\hline 5 & ES $>1,1$ & $\begin{array}{c}\text { Sangat } \\
\text { tinggi }\end{array}$ \\
\hline & (Modified from Glass, 1981)
\end{tabular}

This study examines 20 journals in international journals and national journals starting from 2015 to 2020. The criteria for the journals used are: First, the selected journals are journals that contain Problem Based Learning (PBL)-based teaching materials. Second, journals consist of national journals and international journals that have ISBN. Third, the selected journals were published in the last 5 years. Fourth, the selected journals are studies on subjects at the junior high and high school levels.

The variables of this study consisted of the independent variable in the form of teaching materials, the dependent variable in the form of the achievement of student competence, and the intermediary variable. The data in this study is classified as secondary data, which is obtained from previous research from related journals. The data that has been obtained is then analyzed to find out how much influence is given using the 
effect size formula. Then the effect size data that has been obtained is arranged based on the research objectives that have been set.

\section{RESULTS}

The results of this study are the effect of PBL-based teaching materials on student competencies obtained through the effect size equation. A total of 20 journals with different variables were identified, resulting in grouping the effects of PBL-based teaching materials. The results of the grouping can be seen in the following description.

The first result in this study is about the effect of PBL-based teaching materials based on education level. The average value of effect size in terms of the level of education used from 20 articles can be seen in Table 2.

Tabel 2. The Effect of PBL Based Teaching Materials

Based on Education Level

\begin{tabular}{|c|c|c|c|c|}
\hline Journal Code & Educational level & $\mathbf{S E}$ & Mean & Category \\
\hline $\mathrm{J}_{1}$ & High School & 3,88 & \multirow{15}{*}{1,3} & \multirow{15}{*}{ Tinggi } \\
\hline J2 & High School & 1,49 & & \\
\hline $\mathrm{J}_{3}$ & High School & 0,38 & & \\
\hline $\mathrm{J}_{4}$ & High School & 0,98 & & \\
\hline J15 & High School & 0,53 & & \\
\hline J6 & High School & 0,4 & & \\
\hline J7 & High School & 4,19 & & \\
\hline J18 & High School & 0,78 & & \\
\hline J9 & High School & 0,53 & & \\
\hline J10 & High School & 1,24 & & \\
\hline J11 & High School & 2,49 & & \\
\hline J12 & High School & 0,81 & & \\
\hline $\mathrm{J} 13$ & High School & 0,9 & & \\
\hline J19 & High School & 0,5 & & \\
\hline J2O & High School & 0,4 & & \\
\hline J16 & Middle school & 0,59 & \multirow{5}{*}{1,34} & \multirow{5}{*}{ Tinggi } \\
\hline J17 & Middle school & 0,55 & & \\
\hline J5 & Middle school & 4,6 & & \\
\hline J8 & Middle school & 0,3 & & \\
\hline J14 & Middle school & 0,66 & & \\
\hline
\end{tabular}


Based on the 20 journals analyzed, there are 15 journals at the high school level and 5 journals at the junior high school level. Based on the data in Table 2, it is known that the use of PBL-based teaching materials at the junior and senior high school levels has an average effect size value of 1.3 and 1.34 which are classified as high. This means that PBL-based teaching materials are suitable for use in junior and senior high school students in improving learning outcomes.

The second result in this study is the effect of PBL-based teaching materials on the skills of students. Based on the 20 journals analyzed, there are several skills of students, namely science process skills, learning outcomes and critical thinking. The effect of PBLbased teaching materials in terms of the objectives to be achieved is shown in Figure 1.

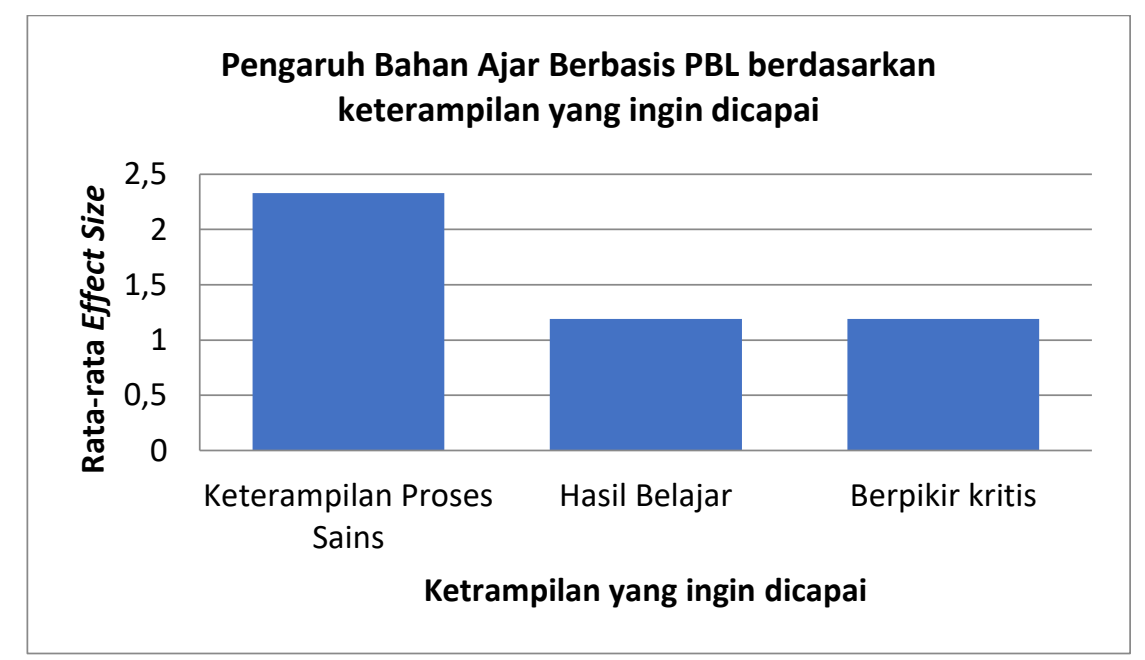

\section{Figure 1. The Effect of PBL-Based Teaching Materials on Student Skills}

Based on Figure 1, it can be seen that PBL-based teaching materials are effective for improving science process skills, learning outcomes, and students' critical thinking skills with high categories. However, when viewed specifically, it can be seen that compared to improving learning outcomes and critical thinking, PBL-based teaching materials have a greater influence in improving students' science process skills.

Science learning is a learning that can stimulate students to improve learning outcomes by using real problems in everyday life. Therefore, the development of PBLbased teaching materials is suitable for improving students' science process skills. This is in accordance with Mayanty et al (2020) who stated that teaching materials developed using the PBL model were effective in improving students' science process skills. With the characteristics of the problem-oriented PBL model, science process skills are one of the right goals in developing a teaching material. 
The third result of this study is the effect of PBL-based teaching materials in terms of the type of teaching materials used. Of the 20 journals identified, there are six types of teaching materials used, namely modules, teaching materials, worksheets, IT media, textbooks and comics. The influence given based on the six types of teaching materials is different as shown in Figure 2.

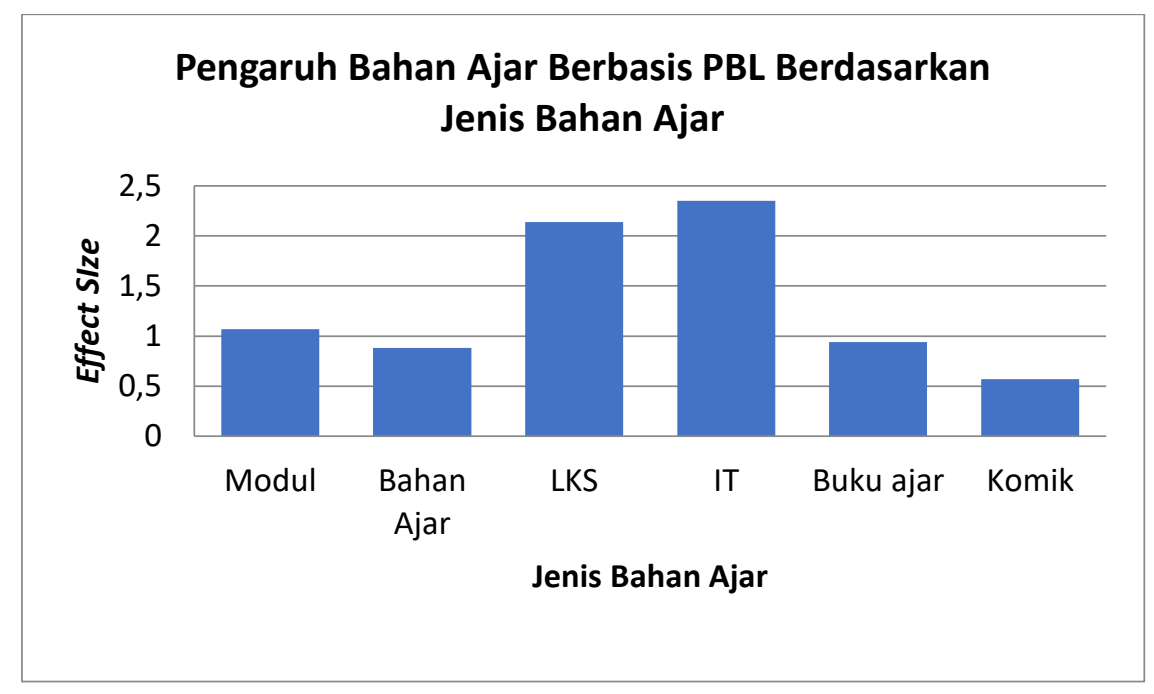

\section{Figure 2. The Influence of PBL Teaching Materials Based on the Type of Teaching Materials}

After processing the data gathered from 20 journals, the effect size value was obtained for each teaching material. The highest effect size value is found in teaching materials in the form of IT of 2.34 which belongs to the high category. Teaching materials in the form of IT are the teaching materials that utilize electronic media. One example of the teaching materials is mobile learning. Mobile learning can be accessed through electronic media, such as gadgets and computers. Based on Figure 2, it can be seen that PBL-based teaching materials in the form of electronic media (IT) are more effective in supporting student learning outcomes. This is in line with Sulaiman et al (2018) which states that IT media with the PBL model can improve student learning outcomes. In addition, IT is very suitable for use in the 21st century because technological advances continue to grow. Besides being able to improve learning outcomes, the use of IT in learning will indirectly increase one of the students' literacy, namely digital literacy. Asrizal et al (2018) suggest that the integration of digital literacy in learning is also important to encourage student success in learning and daily life. Therefore, teaching 
materials that utilize IT can be used as a learning resource to improve student competence in the learning process.

\section{CONCLUSION}

Based on the analysis conducted on 20 journals related to PBL-based teaching materials, there are three conclusions made in this study. First, PBL-based teaching materials are effectively used at the junior and senior high school levels with a high effect size category. Second, PBL-based teaching materials have the highest category of effectiveness in improving science process skills. Third, based on the teaching materials used, teaching materials in the form of PBL-based electronic media (IT) are effective in improving student competence.

\section{REFERENCES}

Asrizal., Amran, A., Festiyed., Sumarmin, R. (2018). The Development of Integrated Science Instructional Materials to Improve Students' Digital Literacy in Scientific Approach. Jurnal Pendidikan IPA Indonesia, 442-450.

Asrizal, Hendri, A., Hidayati, \& Festiyed. (2018). Penerapan Model Pembelajaran Penemuan Mengintegrasikan Laboratorium Virtual dan Hots untuk Meningkatkan Hasil Pembelajaran Siswa SMA Kelas XI. Prosiding Seminar Nasional Hibah Program Dosen ke Sekolah (PDS) (pp. 49-57). Padang: Universitas Negeri Padang.

Depdiknas (2008). Panduan Pengembangan Bahan Ajar. Jakarta: Departemen Pendidikan Nasional.

Dewi, FMC, dkk. (2018). Pengembangan Modul Fisika Berbasis Masalah Pada Materi Termodinamika Untuk Meningkatkan Keterampilan Generik Sains Siswa Kelas XI SMA/MA. Jurnal Inkuiri, 1-12.

Fatimah, Fita dan Arif Widiyatmotoko. (2015). Pengembangan Science Comic Berbasis Problem Based Learning sebagai Media Pembelajaran pada Tema Bunyi Dan Pendengaran untuk Siswa SMP. Unnes Science Education Journal 4 (1).

Glass, G. V., McGaw, B., \& Smith, M. L. (1981). Meta-analysis in Social Research. London: Sage Publication.

Handayani, Ulfatun, dkk. (2017). Pengembangan Modul Fisika Berbasis Problem Based Learning (PBL) untuk Meningkatkan Keterampilan Berpikir Kritis Pada Materi Usaha dan Energi di SMA/MA. Jurnal Inkuiri, 107-116 
Ilahi, Wahyumin Kurnia dan Ramli. (2020). Pengaruh Penerapan Buku Ajar Bermuatan Kecerdasan Komprehensif Dan Model Based Learning Pada Materi Gerak Parabola Dan Gerak Melingkar di Kelas X SMAN 8 Padang. Pillar of Physics Education, 97-104.

Jauhariyah, M. N., Sarwanto, \& Suparmi. Pengembangan Modul Fisika Berbasis Problem Based Learning pada Materi Fluida untuk Siswa Cerdas Istimewa Berbakat Istimewa. Jurnal Pendidikan Fisika Tadulako, Vol. 6 No. 2.

Kurnia, Rizki, dkk. (2018). Penerapan Lks Berbasis Problem Based Learning Terhadap Hasil Belajar Fisika Siswa Kelas X SMAN 1 Batipuh . Seminar Nasional Pendidikan Matematika dan Sains, IAIN Batusangkar Keterampilan Abad 21; Strategi Pengembangan Pembelajaran, Penelitian, Matematika dan Sains.

Liana, Yeni Rima, dkk. (2020). Interactive Mobile Learning Media To Improve Students' Hots Ability Supported With Problem-Based Learning Model. Jurnal Pendidikan Fisika Vol 9. No. 1.

Mardiansa, Rizky, dkk. Pengaruh Model Problem Based Learning terhadap Hasil Belajar Fisika Siswa Materi Fluida Statis di SMA Negeri 6 Palu. Jurnal Pendidikan Fisika Tadulako Online (JPFT) Vol. 6 No. 2

Mayanty, S., Astra, I. M., \& Rustana, C. E. (2020). Efektifitas Penerapan E-Modul Berbasis Problem Based Learning (PBL) terhadap Keterampilan Proses Sains Siswa SMA. Navigation Physics, 98-105.

Novita, Bukit, N., \& Sirait, M. (2019). Pengaruh Model Problem Based Learning Menggunakan Mind Map terhadap Kemmapuan Berpikir Kritis dan Keterampilan Pemecahan Masalah Fisika Siswa SMA . Jurnal Pendidikan Fisika (universitas Negeri Medan), 57-67.

Nurhayati, D. I., Yulianti, D., \& Mindyarto, B. N. (2019). Bahan ajar Berbasis Problem Based Learning pada Materi Gerak Lurus untuk Meningkatkan Kemampuan Komunikasi dan Kolaborasi Siswa. Unnes Physics Education Journal, 208-218.

Perdana, fadel Rista, dkk. Pengaruh Pembelajaran Menggunakan Lembar Kerja Siswa Berbasis Problem Based Learning Pada Materi Fluida Statis Terhadap Hasil Belajar Fisika.

Praptiwi, dkk. (2018). The Effectiveness Of Science Comic On The Materials Of Sound And Hearing Based On Problem Based Learning Toward Junior High School Students' Learning Motivation And Outcome. Unnes Science Education Journal 7 (1). 
Riyanto, \& Aryulina, D. (2016). Problem Based Learning Model in Biology Education Courses to Develop Inquiry Competency of Preservice Teachers. Cakrawala Pendidikan, 47-57.

Saidah, Naila, dkk. (2014). Pengembangan Lks Ipa Terpadu Berbasis Problem Based Learning Melalui Lesson Study Tema Ekosistem Dan Pelestarian Lingkungan. Unnes Science Education Journal 3 (2).

Sanjaya, W. (2006). Startegi Pembelajaran. Jakarta: Kencana.

Sudjana. (2002). Metoda Statistika Edisi ke-6. Bandung: Tarsito.

Sulaiman, Haji, A. G., \& Syukri, M. (2018). Penerapan Model Problem Based Learning Berbantuan Information Technology untuk Meningkatkan Hasil Belajar Peserta Didik pada Materi Fluida Statis. Jurnal Pendidikan Matematika dan IPA, 89-97.

Suparno, Joko, dkk. (2019). Pengembangan Modul IPA Terpadu Untuk SMP/MTs Berbasis Problem Based Learning (PBL) Dengan Tema Fotosintesis ntuk Meningkatkan Kemampuan Berpikir Kritis. INKUIRI: Jurnal Pendidikan IPA, 119-128.

Syam, J., Asrizal, \& Kamus, Z. (2017). Pengaruh Buku Ajar Bermuatan Kecerdasan Komprehensif dalam Model Pembelajaran Berbasis Masalah Terhadap Kompetensi Fisika Peserta Didik Kelas X SMAN 9 Padang. Pillar of Physics, 7380 .

Tarmizi, dkk. (2017). Penggunaan LKS Berbasis PBL Terhadap Keterampilan Berpikir Kritis Siswa pada Materi Cahaya di SMPN 1 Kembang Tanjon. Jurnal Pendidikan Sains Indonesia, 87-93.

Trianto. (2007). Model-model Pembelajaran Inovatid Berorientasi Konstruktivistik. Jakarta: Prestasi Pustaka.

Wagner, T. (2010). Overcoming The Global Achievement Gap. Cambridge: Harvard University.

Yarid, Hatta dan Ariswan. (2016). Pengembangan Perangkat Pembelajaran Fisika Problem Based Learning Melalui Kegiatan Fieldtrip pada Materi Energi. Jurnal Inovasi Pendidikan IPA, 24-34. 